University of Nebraska - Lincoln

DigitalCommons@University of Nebraska - Lincoln

\title{
Gene transcription in sea otters (Enhydra lutris); development of a diagnostic tool for sea otter and ecosystem health
}

\author{
Lizabeth Bowen \\ Western Ecological Research Center, Ibowen@usgs.gov
}

A. Keith Miles

Western Ecological Research Center, keith_miles@usgs.gov

Michael Murray

Monterey Bay Aquarium

Martin Haulena

Vancouver Aquarium, Martin.Haulena@vanaqua.org

Judy Tuttle

Oregon Coast Museum, judy.tuttle@aquarium.org

See next page for additional authors

Follow this and additional works at: https://digitalcommons.unl.edu/usgsstaffpub

Part of the Geology Commons, Oceanography and Atmospheric Sciences and Meteorology Commons, Other Earth Sciences Commons, and the Other Environmental Sciences Commons

Bowen, Lizabeth; Miles, A. Keith; Murray, Michael; Haulena, Martin; Tuttle, Judy; Van Bonn, William; Adams, Lance; Bodkin, James L.; Ballachey, Brenda; Estes, James A.; Tinker, M. Tim; Keister, Robin; and Stott, Jeffrey L., "Gene transcription in sea otters (Enhydra lutris); development of a diagnostic tool for sea otter and ecosystem health" (2012). USGS Staff -- Published Research. 521.

https://digitalcommons.unl.edu/usgsstaffpub/521

This Article is brought to you for free and open access by the US Geological Survey at DigitalCommons@University of Nebraska - Lincoln. It has been accepted for inclusion in USGS Staff -- Published Research by an authorized administrator of DigitalCommons@University of Nebraska - Lincoln. 


\section{Authors}

Lizabeth Bowen, A. Keith Miles, Michael Murray, Martin Haulena, Judy Tuttle, William Van Bonn, Lance

Adams, James L. Bodkin, Brenda Ballachey, James A. Estes, M. Tim Tinker, Robin Keister, and Jeffrey L. Stott 


\title{
Gene transcription in sea otters (Enhydra lutris); development of a diagnostic tool for sea otter and ecosystem health
}

\author{
LIZABETH BOWEN,* A. KEITH MILES,* MICHAEL MURRAY,† MARTIN HAULENA, $\ddagger$ JUDY TUTTLE,§ \\ WILLIAM VAN BONN, II LANCE ADAMS, ${ }^{* *}$ JAMES L. BODKIN, †+ BRENDA BALLACHEY, ††

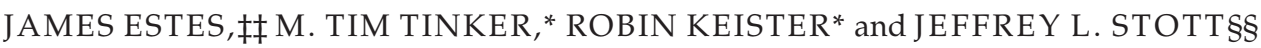 \\ *U.S. Geological Survey, Western Ecological Research Center, Sacramento, CA 95826, USA, +Monterey Bay Aquarium, Monterey, \\ CA 93940, USA, ‡Vancouver Aquarium, Vancouver, BC V6G 3E2, Canada, §Oregon Coast Museum, Newport, OR 97365, USA, \\ IIShedd Aquarium, Chicago, IL 60605, USA, **Aquarium of the Pacific, Long Beach, CA 90802, USA, ++U.S. Geological Survey, \\ Alaska Science Center, Anchorage, AK 99508, USA, 扯University of California, Santa Cruz, CA 95064, USA, §§University of \\ California, Davis, CA 95616, USA
}

\begin{abstract}
Gene transcription analysis for diagnosing or monitoring wildlife health requires the ability to distinguish pathophysiological change from natural variation. Herein, we describe methodology for the development of quantitative real-time polymerase chain reaction (qPCR) assays to measure differential transcript levels of multiple immune function genes in the sea otter (Enhydra lutris); sea otter-specific qPCR primer sequences for the genes of interest are defined. We establish a 'reference' range of transcripts for each gene in a group of clinically healthy captive and free-ranging sea otters. The 10 genes of interest represent multiple physiological systems that play a role in immuno-modulation, inflammation, cell protection, tumour suppression, cellular stress response, xenobiotic metabolizing enzymes, antioxidant enzymes and cell-cell adhesion. The cycle threshold $\left(C_{\mathrm{T}}\right)$ measures for most genes were normally distributed; the complement cytolysis inhibitor was the exception. The relative enumeration of multiple gene transcripts in simple peripheral blood samples expands the diagnostic capability currently available to assess the health of sea otters in situ and provides a better understanding of the state of their environment.
\end{abstract}

Keywords: diagnostics, gene transcript, marine ecosystem health, quantitative real-time polymerase chain reaction, sea otter

Received 14 March 2011; accepted 7 July 2011

\section{Introduction}

Gene-based health diagnostics of marine mammals afford opportunity for improved assessment of health not only in individuals or populations but also potentially in ecosystems (Acevedo-Whitehouse \& Duffus 2009). Marine mammals are widely recognized as keystone species in nearshore and oceanic ecosystems with social appeal as highly popular, viewable wildlife. Further, marine mammals are generally apex predators in food webs and as such their health and abundance depend upon the productivity and diversity of species at lower trophic levels. Concurrently, predation by marine mammals can directly or indirectly affect ecosystem

Correspondence: Lizabeth Bowen, Fax: (530) 754 9141;

E-mail: lbowen@usgs.gov structure and function, in some cases influencing entire landscapes and associated patterns of biodiversity (Estes 2009; Terborgh \& Estes 2010; Estes et al. 2011). The sea otter, Enhydra lutris, which is a textbook example of a keystone predator that can exert profound effects on multiple trophic levels of nearshore communities (Estes \& Duggins 1995), is susceptible to a variety of ecological and environmental stressors (Estes et al. 1997; Johnson et al. 2009). Consequently, wide spectrum, diagnostic evaluation into the health of sea otters can serve as an indication of overall ecosystem health and stability.

Despite the urgent need for ecological studies of marine mammal health including mechanisms of disease resistance (Harvell et al. 1999), the development of molecular genetic information or tools for biomedical research in marine mammals has been slow compared with human or domestic veterinary medicine (Mancia et al. 
2008). However, applying contemporary gene transcript analysis to identify genomic response to environmental stress or disease has the potential to transform marine mammal diagnostics (Burczynski et al. 2000; Bartosiewicz et al. 2001). Advanced technologies, based and developed upon the well-studied biomedical models of human physiology and disease, are aiding researchers with cutting-edge diagnostic tools for both domestic and wildlife veterinary applications (Burczynski et al. 2000; Bartosiewicz et al. 2001; Bowen et al. 2007; Sitt et al. 2008).

The advantage of using gene transcript analysis in marine mammal diagnostics lies in the capacity to measure physiologic responses (acute or chronic) of an individual to environmental stressors; the earliest observable signs of health impairment are altered levels of gene transcripts, evident prior to clinical manifestation (McLoughlin et al. 2006). Consequently, clinical application of quantitative gene transcript analysis technology will provide an invaluable addition to current approaches for monitoring indications of potential health impairment (McLoughlin et al. 2006). However, a key requirement for clinical application of gene transcript technology is the establishment of a normal or 'reference' range of values, distinguishing between natural variation in gene transcript levels among healthy subjects and changes associated with compromised health (McLoughlin et al. 2006). Reference ranges for gene transcript analysis in wildlife populations are lacking (Mancia et al. 2008; Sitt et al. 2008).

Herein, we describe the development of species-specific quantitative real-time polymerase chain reaction (qPCR) assays to measure differential transcript levels of multiple genes in the sea otter, and subsequent establishment of a 'reference' range for each of 10 genes of interest in peripheral blood leucocytes. The genes described are fundamental to mediation of detoxification and immune function (Schwartz et al. 2004a,b), cellular injury (Ghanem et al. 2006), signal transduction (Burchiel \& Luster 2001), xenobiotic metabolism (Schwartz et al. 2004a,b) or tumorigenesis (Ramesh et al. 2004) (Table 1). Such an evaluation of gene transcript levels in sea otters can provide insight into their physiological response to different suites of environmental or disease stressors and may act as an indicator of immune impairment in individuals as well as populations.

The development of the sea otter-specific gene transcription-based diagnostic panel was prefaced by a study of ranch mink (Mustela vison) as a model for petroleum oil exposure in mustelids (Bowen et al. 2007). In that study, the pathophysiologic effects of oil exposure impacted multiple organ systems and multiple physiological pathways in the mink. Bowen et al. (2007) demonstrated that characteristic and specific patterns of gene transcription were reflective of oil exposure and concur- rently provided a basis for evaluating general immunologic vigour and health of free-ranging sea otter populations. Phenotypic evidence of xenobiotic effects on sea otters generally has been slow to emerge. Moreover, field diagnoses by wildlife veterinarians provide only a rough assessment of overall wildlife health, particularly in remote locations where time-sensitive or methodintensive laboratory testing is not possible. Measurement of differential transcription of a selected suite of genes potentially can provide an early warning of compromised health and related environmental stressors in free-ranging animals.

\section{Materials and methods}

\section{Captive otters}

Seventeen blood samples from captive sea otters (Enhydra lutris) were obtained from the Monterey Bay Aquarium (Monterey, CA, USA), Shedd Aquarium (Chicago, IL, USA), Oregon Coast Aquarium (Newport, OR, USA) or the Vancouver Aquarium (Vancouver, BC, Canada) in 2008, 2009 and 2010 (Table 2). These animals were identified as clinically normal by staff veterinarians at these aquaria during the time interval preceding blood collection.

\section{Free-ranging otters}

Sea otters were captured in Alaska, along the south-western Alaska Peninsula ( $n=25$; summer 2009; Table 2). Sea otters were captured using Wilson traps (Wendell et al. 1996) or tangle nets, transported immediately to a shipboard station, immobilized with fentanyl citrate and midazolam hydrochloride and processed (Monson et al. 2001). All captured sea otters were determined to be clinically normal by the attending veterinarian at the time of capture. None of the otters, captive or free-ranging, was pregnant at the time of sampling.

\section{Blood collection and RNA extraction}

A $2.5 \mathrm{~mL}$ sample from each sea otter was drawn directly into a PAXgene ${ }^{\mathrm{TM}}$ blood RNA collection tube (PreAnalytiX, Switzerland) from either the jugular or popliteal veins and then frozen at $-20{ }^{\circ} \mathrm{C}$ until extraction of RNA. Rapid RNA degradation and induced transcription of certain genes after blood draws has led to the development of methodologies for preserving the RNA transcription profile immediately after blood is drawn. The PAXgene ${ }^{\mathrm{TM}}$ tube contains a blend of RNA-stabilizing reagents that protect RNA molecules from degradation by RNases and prevent induction of gene transcription. Without this stabilization, copy numbers of individual mRNA species in 
Table 1 Genes selected for the diagnostic panel and their primary functions

\begin{tabular}{|c|c|}
\hline Gene & Gene function \\
\hline$H D C$ & $\begin{array}{l}\text { The HDCMB21P gene codes for a translationally controlled tumour protein implicated in cell growth, cell cycle } \\
\text { progression, malignant transformation, tumour progression and in the protection of cells against various stress } \\
\text { conditions and apoptosis (Bommer \& Thiele 2004; Tuynder et al. 2004; Ma et al. 2009). Up-regulation of HDC is } \\
\text { indicative of the development or existence of cancer. Environmental triggers may be responsible for population-based } \\
\text { up-regulation of HDC. HDC transcription is known to increase with exposure to carcinogenic compounds } \\
\text { such as polycyclic aromatic hydrocarbons (Bowen et al. 2007; Raisuddin et al. 2007; Zheng et al. 2008). }\end{array}$ \\
\hline COX2 & $\begin{array}{l}\text { Cyclooxygenase- } 2 \text { catalyses the production of prostaglandins that are responsible for promoting inflammation (Goldsby } \\
\text { et al. 2003). Cox } 2 \text { is responsible for the conversion of arachidonic acid to prostaglandin H2, a lipoprotein critical to the } \\
\text { promotion of inflammation (Harris. et al. 2002). Up-regulation of Cox } 2 \text { is indicative of cellular or tissue damage and an } \\
\text { associated inflammatory response. }\end{array}$ \\
\hline$C Y T$ & $\begin{array}{l}\text { The complement cytolysis inhibitor protects against cell death (Jenne \& Tschopp 1989). Up-regulation of CYT is indicative } \\
\text { of cell or tissue death. }\end{array}$ \\
\hline$A H R$ & $\begin{array}{l}\text { The arylhydrocarbon receptor responds to classes of environmental toxicants including polycyclic aromatic hydrocarbons, } \\
\text { polyhalogenated hydrocarbons, dibenzofurans and dioxin (Oesch-Bartlomowicz \& Oesch 2005). Depending upon the } \\
\left.\text { ligand, AHR signalling can modulate T-regulatory ( } \mathrm{T}_{\mathrm{REG}} \text { ) (immune-suppressive) or T-helper type } 17 \text { ( } \mathrm{T}_{\mathrm{H}} 17\right) \\
\text { (pro-inflammatory) immunologic activity (Quintana et al. 2008; Veldhoen et al. 2008). }\end{array}$ \\
\hline THR & $\begin{array}{l}\text { The thyroid hormone receptor beta can be used as a mechanistically based means of characterizing the thyroid-toxic } \\
\text { potential of complex contaminant mixtures (Tabuchi et al. 2006). Thus, increases in THR transcription may indicate } \\
\text { exposure to organic compounds including PCBs and associated potential health effects such as developmental } \\
\text { abnormalities and neurotoxicity (Tabuchi et al. 2006). Hormone-activated transcription factors bind DNA in the } \\
\text { absence of hormone, usually leading to transcriptional repression (Tsai \& O'Malley 1994). }\end{array}$ \\
\hline HSP 70 & $\begin{array}{l}\text { The heat shock protein } 70 \text { is produced in response to thermal or other stress (Iwama et al. 1999; Tsan \& Gao 2004). } \\
\text { In addition to being expressed in response to a wide array of stressors (including hyperthermia, oxygen radicals, heavy } \\
\text { metals and ethanol) heat shock proteins act as molecular chaperones (De Maio 1999). For example, heat shock proteins } \\
\text { aid the transport of the AHR/toxin complex in the initiation of detoxification (Tanabe et al. 1994). }\end{array}$ \\
\hline IL-18 & $\begin{array}{l}\text { Interleukin-18 is a pro-inflammatory cytokine (Goldsby et al. 2003). Plays an important role in inflammation and host } \\
\text { defence against microbes (Krumm et al. 2008). }\end{array}$ \\
\hline IL-10 & $\begin{array}{l}\text { Interleukin-10 is an anti-inflammatory cytokine (Goldsby et al. 2003). Levels of IL-10 have been correlated with relative } \\
\text { health of free-ranging harbour porpoises, e.g. increased amounts of IL-10 correlated with chronic disease whereas the } \\
\text { cytokine was relatively reduced in apparently fit animals experiencing acute disease (Beineke et al. 2007). Association of } \\
\text { IL-10 transcription with chronic disease has also been documented in humans (Rigopoulou et al. 2005). }\end{array}$ \\
\hline$D R B$ & $\begin{array}{l}\text { A component of the major histocompatibility complex, the DRB class II gene, is responsible for the binding and } \\
\text { presentation of processed antigen to } \mathrm{T}_{\mathrm{H}} \text { lymphocytes, thereby facilitating the initiation of an immune response (Goldsby } \\
\text { et al. 2003; Bowen et al. 2006). Up-regulation of MHC genes has been positively correlated with parasite load (Wegner } \\
\text { et al. 2006), whereas down-regulation of MHC has been associated with contaminant exposure (Dong et al. 1997). }\end{array}$ \\
\hline$M x 1$ & $\begin{array}{l}\text { The Mx1 gene responds to viral infection (Tumpey et al. 2007). Vertebrates have an early strong innate immune response } \\
\text { against viral infection, characterized by the induction and secretion of cytokines that mediate an antiviral state, leading to } \\
\text { the up-regulation of the MX-1 gene (Kibenge et al. 2005). }\end{array}$ \\
\hline
\end{tabular}

whole blood can change more than 1000-fold during storage and transport. The RNA from blood in PAXgene ${ }^{\mathrm{TM}}$ tubes was isolated according to manufacturer's standard protocols, which included an on-column DNase treatment to remove contaminating gDNA (silica-based microspin technology), and the extracted RNA stored at $-80{ }^{\circ} \mathrm{C}$ until analysis.

\section{cDNA creation}

A standard cDNA synthesis was performed on $2 \mu \mathrm{g}$ of RNA template from each animal. Reaction conditions included four units reverse transcriptase (Omniscript ${ }^{\circledR}$; Qiagen, Valencia, CA, USA), $1 \mu \mathrm{M}$ random hexamers, $0.5 \mathrm{~mm}$ each dNTP and 10 units RNase inhibitor, in RT buffer (Qiagen). Reactions were incubated for $60 \mathrm{~min}$ at $37^{\circ} \mathrm{C}$, followed by an enzyme inactivation step of $5 \mathrm{~min}$ at $93{ }^{\circ} \mathrm{C}$, and then stored at $-20{ }^{\circ} \mathrm{C}$ until further analysis.

\section{PCR primers}

Degenerate primers were designed based upon multispecies alignments (GenBank) as previously described (Bowen et al. 2007). Briefly, degenerate primer pairs developed for the American mink (Neovison vison) (Bowen et al. 2007) were utilized on cDNA from three randomly selected sea otter samples. Degenerate primer pairs were designed to amplify 10 genes of interest and one ribosomal or housekeeping gene (Bowen et al. 2007). PCR amplifications using these primers were performed 
Table 2 Location, age (at time of blood draw), sex and subspecies of 17 healthy captive otters and 25 healthy free-ranging otters

\begin{tabular}{|c|c|c|c|c|}
\hline $\begin{array}{l}\text { Animal } \\
\text { ID }\end{array}$ & $\begin{array}{l}\text { Aquarium/geographic } \\
\text { location }\end{array}$ & $\begin{array}{l}\text { Age, } \\
\text { years }\end{array}$ & Sex & Circumstance of captivity \\
\hline 1 & Monterey Bay Aquarium & 7 & $\mathrm{~F}$ & Injured adult, Monterey Harbor, Monterey, CA \\
\hline 2 & Monterey Bay Aquarium & 1 & $\mathrm{~F}$ & Orphaned pup from Carmel Point, Carmel, CA \\
\hline 3 & Monterey Bay Aquarium & 1 & $\mathrm{M}$ & Orphaned pup from Cayucos, CA \\
\hline 4 & Monterey Bay Aquarium & 1 & $\mathrm{~F}$ & Orphaned pup from Fanshell Beach, Pebble Beach, CA \\
\hline 5 & Monterey Bay Aquarium & 12 & $\mathrm{~F}$ & Orphaned pup from Twin Lakes Beach, Santa Cruz, CA \\
\hline 6 & Monterey Bay Aquarium & 8 & $\mathrm{~F}$ & Orphaned pup from Carchoran Lagoon, Santa Maria Beach, CA \\
\hline 7 & Monterey Bay Aquarium & 9 & $\mathrm{~F}$ & Orphaned pup from San Simeon State Park, CA \\
\hline 8 & $\begin{array}{l}\text { Monterey Bay Aquarium } \\
\text { (Long Marine Laboratory, } \\
\text { U Cal Santa Cruz) }\end{array}$ & 7 & $\mathrm{M}$ & Morro Bay Harbor, CA \\
\hline 9 & Monterey Bay Aquarium & 11 & $\mathrm{~F}$ & Orphaned pup from Monterey Bay, CA \\
\hline 10 & Vancouver Aquarium & 7 & $\mathrm{M}$ & Orphaned pup from Seward Alaska \\
\hline 11 & Vancouver Aquarium & 9 & $\mathrm{M}$ & Captive born from Lisbon Aquarium \\
\hline 12 & Oregon Coast Aquarium & 10 & $\mathrm{M}$ & Orphaned pup found near Aialik Glacier, Alaska \\
\hline 13 & Oregon Coast Aquarium & 12 & $\mathrm{M}$ & Orphaned pup found on Asilomar Beach, CA \\
\hline 14 & Shedd Aquarium & 20 & $\mathrm{~F}$ & Orphaned pup found near Homer, Alaska \\
\hline 15 & Shedd Aquarium & 7 & $\mathrm{~F}$ & Orphaned pup found in Alaska \\
\hline 16 & Shedd Aquarium & 5 & $\mathrm{~F}$ & Orphaned pup found in Alaska \\
\hline 17 & Shedd Aquarium & 10 & $\mathrm{M}$ & Born, Seattle Aquarium \\
\hline $18-23$ & Alaska Peninsula & $1-3$ & $\mathrm{M}$ & Free-ranging, Wilson trap \\
\hline $24-25$ & Alaska Peninsula & $1-3$ & $\mathrm{~F}$ & Free-ranging, Wilson trap \\
\hline $26-31$ & Alaska Peninsula & $4-8$ & $\mathrm{M}$ & Free-ranging, Wilson trap \\
\hline $32-40$ & Alaska Peninsula & $4-8$ & $\mathrm{~F}$ & Free-ranging, Wilson trap \\
\hline 41 & Alaska Peninsula & $9-15$ & M & Free-ranging, Wilson trap \\
\hline 42 & Alaska Peninsula & $9-15$ & $\mathrm{~F}$ & Free-ranging, Wilson trap \\
\hline
\end{tabular}

on $20 \mathrm{ng}$ of each cDNA sample in $50 \mu \mathrm{L}$ volumes containing 20-60 pmol of each primer, $40 \mathrm{~mm}$ Tris- $\mathrm{KOH}$ ( $\mathrm{pH}$ 8.3), $15 \mathrm{~mm} \mathrm{KOAc,} 3.5 \mathrm{~mm} \mathrm{Mg}(\mathrm{OAc})_{2}, 3.75 \mu \mathrm{g} / \mathrm{mL}$ bovine serum albumin, $0.005 \%$ Tween-20, 0.005\% Nonidet-P40, $200 \mu \mathrm{M}$ each dNTP and 5U of Advantage ${ }^{\circledR} 2$ Taq polymerase (Clontech, Palo Alto, CA). The PCR was performed on an MJ Research PTC-200 thermal cycler (MJ Research, Watertown, MA, USA) and consisted of one cycle at $94{ }^{\circ} \mathrm{C}$ for $3 \mathrm{~min}$, and then 40 cycles at $94{ }^{\circ} \mathrm{C}$ for $30 \mathrm{~s}$, at $60{ }^{\circ} \mathrm{C}$ for $30 \mathrm{~s}$, and $72{ }^{\circ} \mathrm{C}$ for $2 \mathrm{~min}$, with a final extension step of $72{ }^{\circ} \mathrm{C}$ for $10 \mathrm{~min}$. The products of these reactions were electrophoresed on $1.5 \%$ agarose gels and resulting bands visualized by ethidium bromide staining. Definitive bands representing PCR products of a predicted base pair size of the targeted gene were excised from the gel, and extracted and purified using a commercially available nucleic acid-binding resin (Qiaex II Gel extraction kit; Qiagen).

Isolated fragments were ligated into a T/A-type cloning vector ( $\mathrm{pGEM}{ }^{\circledR}-\mathrm{T}$ Easy vector systems; Promega, Madison, WI, USA). Following transformation, growth and blue-white selection in competent cells (SE DH5 $\alpha$ competent cells; Life Technologies Inc., Rockville, MD, USA), the DNA from positive clones was isolated. Nucleotide sequences of both strands were determined by dideoxy nucleotide methodology using an automated sequencer (Model 373; Applied Biosystems, Foster City, CA, USA). Nucleotide sequences of the PCR products were analysed using Align ${ }^{\mathrm{TM}}$ and Contig ${ }^{\mathrm{TM}}$ sequence alignment software programs (Vector NTI' ${ }^{\mathrm{TM}}$; Informax Inc., North Bethesda, MD, USA) and compared with known sequences using the NCBI BLAST program (Altschul et al. 1990), and the IMGT/HLA database (Robinson et al. 2001). Primer pairs appropriate for real-time PCR were designed based on the elucidated sea otter sequences for each gene.

\section{Real-time PCR}

Real-time PCR systems for the individual, sea otter-specific housekeeping gene (S9) and genes of interest were run in separate wells. Briefly, $1 \mu \mathrm{L}$ of cDNA was added to a mix containing $12.5 \mu \mathrm{L}$ of QuantiTect SYBR Green ${ }^{\circledR}$ Master Mix [5 mM Mg${ }^{2+}$ ] (Qiagen), $0.5 \mu \mathrm{L}$ each of forward and reverse sequence-specific primers, $0.5 \mu \mathrm{L}$ of Uracil-N-Glycosylase (Invitrogen, Carlsbad, CA, USA) and $10.0 \mu \mathrm{L}$ of RNase-free water; total reaction mixture was $25 \mu \mathrm{L}$. The reaction mixture cDNA samples for each gene of interest and S9 were loaded into 96-well plates in duplicate and sealed with optical sealing tape (Applied 
Biosystems). Reaction mixtures containing water, but no cDNA, were used as negative controls; thus, approximately three-four individual sea otter samples were run per plate.

Amplifications were conducted on a 7300 real-time thermal cycler (Applied Biosystems). Reaction conditions were as follows: $50{ }^{\circ} \mathrm{C}$ for $2 \mathrm{~min}, 95^{\circ} \mathrm{C}$ for $15 \mathrm{~min}, 40$ cycles of $94{ }^{\circ} \mathrm{C}$ for $30 \mathrm{~s}, 58^{\circ} \mathrm{C}$ for $30 \mathrm{~s}, 72{ }^{\circ} \mathrm{C}$ for $31 \mathrm{~s}$, an extended elongation phase at $72{ }^{\circ} \mathrm{C}$ for $10 \mathrm{~min}$. Reaction specificity was monitored by melting curve analysis using a final data acquisition phase of 60 cycles of $65^{\circ} \mathrm{C}$ for $30 \mathrm{~s}$ and verified by direct sequencing of randomly selected amplicons (Bowen et al. 2007). Cycle threshold crossing values $\left(C_{\mathrm{T}}\right)$ for the genes of interest were normalized to the S9 housekeeping gene.

\section{Statistical analysis}

Analysis of qPCR data were conducted using normalized values (housekeeping gene threshold crossing subtracted from the gene of interest threshold crossing); the lower the normalized value, the more transcripts are present. A change in normalized value of 2 is approximately equivalent to a fourfold change in the amount of the transcript.

Commonly used parametric tests to distinguish differential gene transcription among populations are based partly on the assumption that the values being compared were sampled from normally distributed populations. We tested the assumption that transcript levels of our genes of interest were log-normally distributed, to use such tests for detection of disease or environmental stressors (McLoughlin et al. 2006). Geometric means and 95\% upper and lower confidence limits were computed, and Anderson-Darling and
Shapiro-Wilk tests for normality were performed for all genes (NCSS, Statistical and Power Analysis Software, UT, USA).

\section{Results}

Sea otter-specific qPCR primers for the 10 genes of interest determined from captive and free-ranging sea otters are defined in Table 3. Most genes had transcript values following normal distributions; complement cytolysis inhibitor gene was the exception (Table 4). The cyclooxygenase-2 gene most closely followed a normal distribution of normalized values, with a Shapiro-Wilk $P$ value of $\geq 0.58$. All genes had unimodal distributions; the deviations from normality involved small degrees of left skewness. Additionally, the $95 \%$ confidence intervals were

Table 4 Genes of interest in clinically normal sea otter blood samples: means, 95\% upper (ucl) and lower (lcl) confidence levels, and $P$ values for normality tests, based on normalized $C_{\mathrm{T}}$ values

\begin{tabular}{lrrrll}
\hline & $\begin{array}{l}\text { Geometric } \\
\text { mean }\end{array}$ & $95 \%$ lcl & $95 \%$ ucl & $\begin{array}{l}\text { Shapiro- } \\
\text { Wilk }\end{array}$ & $\begin{array}{l}\text { Anderson- } \\
\text { Darling }\end{array}$ \\
\hline HDC & 6.11 & 5.85 & 6.92 & 0.06 & 0.06 \\
COX2 & 6.67 & 6.36 & 7.38 & 0.58 & 0.36 \\
CYT & 2.09 & 2.03 & 2.86 & 0.00 & 0.02 \\
AHR & 10.81 & 10.45 & 11.37 & 0.40 & 0.21 \\
THRB & 13.12 & 12.65 & 13.91 & 0.42 & 0.38 \\
HSP70 & 8.99 & 8.61 & 9.68 & 0.47 & 0.36 \\
IL-18 & 1.67 & 1.34 & 2.20 & 0.12 & 0.16 \\
IL-10 & 13.22 & 12.77 & 13.91 & 0.05 & 0.06 \\
DRB & -0.64 & -1.11 & -0.24 & 0.26 & 0.11 \\
Mx1 & 11.52 & 11.08 & 12.28 & 0.13 & 0.06 \\
\hline
\end{tabular}

See Table 1 for interpretation of gene abbreviations.

Table 3 Sea otter-specific quantitative real-time polymerase chain reaction primers used in the analysis of free-ranging and captive otters

\begin{tabular}{|c|c|c|c|c|c|}
\hline Gene & $\begin{array}{l}\text { Forward } \\
\text { primer }\end{array}$ & Sequence $\left(5^{\prime} \rightarrow 3^{\prime}\right)$ & $\begin{array}{l}\text { Reverse } \\
\text { primer }\end{array}$ & Sequence $\left(5^{\prime} \rightarrow 3^{\prime}\right)$ & $\begin{array}{l}\text { Tm of } \\
\text { amplicon }\end{array}$ \\
\hline$H D C$ & Enlu HDC F & ATGTTCTCCGACAT & Enlu HDC R & GTTTCCTGCAGGTG & 82.6 \\
\hline COX2 & Enlu COX2 F & CATTCCTGATCCСC & Enlu COX2 R & GTCCACCCCATGGC & 79.4 \\
\hline$C Y T$ & Enlu CYT F & GCTGGACGAGCAGT & Enlu CYT R & GACGCCAGAGGGAG & 81.8 \\
\hline$A H R$ & Enlu AHR F & GCGCTGAGTACCAT & Enlu AHR R & CACTAAGCGTGCAT & 76.8 \\
\hline THRB & Enlu THR F & GGACAAACCGAAGC & Enlu THR R & GGAATATTGAGCTAAGTCCAAGTGG & 81.8 \\
\hline HSP70 & Enlu HSP70 F & CCAGGTGGCGCTGAACCCGC & Enlu HSP70 R & СCTTGTAGCTCACCTGCACCTTG & 85.6 \\
\hline$I L-18$ & Enlu IL18 F & GTACAGAAAACGCATCCCATACC & Enlu IL18 R & CTGGAGGTCTCATTTCCTTAAAGG & 76.2 \\
\hline$I L-10$ & Enlu IL10 F & GACTTTAAGGGTTACCTGGGTTGC & Enlu IL10 R & TCCACGGCCTTGCTCTTGTTGTC & 83.7 \\
\hline$M H C D R B$ & Enlu DRB F & CGGCGAGTGGAGCCTATAGTG & Enlu DRB R & СТССТСTTCСТGGCCATTCCG & 81.0 \\
\hline$M x 1$ & $\begin{array}{c}\text { Enlu MX1 } \\
\text { express F }\end{array}$ & CAAGCAGCTCATCAGGAAGTACA & $\begin{array}{c}\text { Enlu Mx1 } \\
\text { express R }\end{array}$ & GGTGGCGATGTCCACGTT & 79.5 \\
\hline S9 & Enlu S9 F & CCAGCGCCACATCAGGGTCCG & Enlu S9 R & CCCTGGCCTTTCTTGGCGTTC & 83.4 \\
\hline
\end{tabular}

See Table 1 for interpretation of gene abbreviations. 


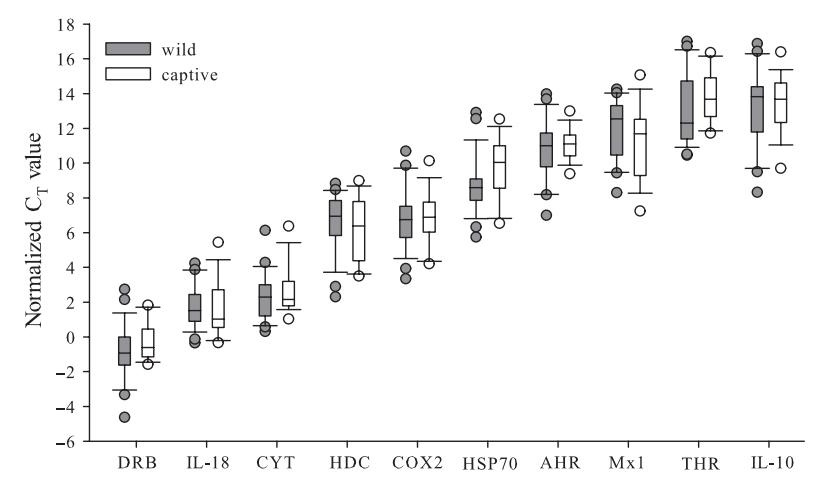

Fig. 1 Distribution of average cycle threshold $\left(C_{\mathrm{T}}\right)$ values across genes targeted by the panel of ten primer sets. Blood was sampled from clinically normal aquaria $(n=17)$ and free-ranging $(n=25)$ sea otters. Bars range from the 10th to the 90th percentile of normalized values for each gene. Circles represent 5 th and 95th percentile outliers. Interpretation of gene abbreviations is provided in Table 1.

independent of the mean normalized values, indicating that the dynamic ranges did not depend upon a gene's transcript level (Fig. 1). Moreover, normalized values did not differ between groups.

\section{Discussion}

Our study describes the first leucocyte gene transcript data for sea otters and represents the necessary first step towards establishing normal reference ranges for these genes. Acquisition of a blood leucocyte transcript profile has the potential to identify stressed or diseased animals prior to the onset of clinical signs. The genes targeted in our study were largely selected based upon a suite of genes transcripts previously demonstrated to be significantly altered in American mink that were experimentally exposed to crude oil (Bowen et al. 2007). This gene transcript profile included a combination of immune response genes with potential to be modified by biological, physical or anthropogenic injury and consequently provide information on the type and magnitude of stressor present in the animal's environment. The results of our study demonstrate that establishment of gene transcript profiles in peripheral blood samples has the potential to extend diagnostic capabilities beyond those currently available to assess the health of sea otters, both individually and as populations.

Traditional evaluation of the health status of a sea otter is based upon a combination of the animal's history, physical examination and clinical pathology data. For free-ranging sea otters, there is likely to be little historical data available, whereas captive sea otters are accompanied by an extensive set of historical data, including diet records and behavioural information, as well as the results of previous physical examinations and laboratory evaluations.

The inherently aggressive nature of even 'tame' captive sea otters precludes a thorough physical examination without adequate chemical immobilization. In most cases, a combination of fentanyl citrate and midazolam hydrochloride administered intra-muscularly provides the degree of sedation necessary to perform a thorough physical examination and collect the suite of biomedical samples required for health assessment (Monson et al. 2001). The physical examination is a complete 'nose-totoes' examination commensurate with similar procedures in domestic carnivores. While there are a number of idiosyncrasies in sea otter anatomy and physiology, their interpretation in the process is readily accomplished by veterinarians experienced in sea otter medicine. In most cases, the minimum clinical pathology database includes a complete blood count (CBC), serum chemistry panel, and, if available, urinalysis. Clinical pathology data are evaluated in conjunction with the history and physical examination findings and compared with published reference ranges (Williams 1983, 1992; Ballachey et al. 2003).

Determination of 'normal' or 'healthy' in any animal, particularly wildlife, is problematic. In general, this determination is a relative one, with the findings in one individual being compared and contrasted with reference standards developed from similar populations. Despite the publication of several sets of reference ranges for sea otter $\mathrm{CBC}$ /serum chemistry data, one might anticipate potential differences between various wild populations, captive animals, as well as a number of 'normal' physiologic differences attributable to sex, age and reproductive state (Walton 2001). For that reason, clinical pathology data tend to be interpreted more conservatively than physical examination findings.

Establishment of a normal reference range for gene transcript panels is critical for use in wildlife and ecosystem health monitoring (Mancia et al. 2008). Variation in gene transcripts does occur in healthy individuals and can be attributed to both intrinsic and extrinsic factors (McLoughlin et al. 2006). Additionally, some of the apparently healthy otters in this study may have included individuals with illness at subclinical detection levels. However, variation in transcripts from our reference otters is small. Considering the number of factors that can affect the transcription of genes in a healthy population (McLoughlin et al. 2006), it is remarkable that the overall dynamic range of transcription was not wider than observed in the current study.

Our results represent a foundation upon which diagnostic panels can be developed for use in the analysis of sea otter population health and response to external stimuli. Such an approach will enhance the sensitivity and 
value of the sea otter as a sentinel species for marine ecosystem health.

\section{Acknowledgements}

We gratefully acknowledge the contributions of M. Viens, Registered Veterinary Technician. Samples were provided by the aquaria under the expressed permission of the U.S. Fish and Wildlife Service and under the Animal Care Committee protocols established at each of the aquaria; samples were received from Canada under CITES permit CA10FONHQ0016. Mention of trade names or organizations does not imply endorsement by the U.S. government. The research described in this study was supported by the Exxon Valdez Oil Spill Trustee Council. However, the findings and conclusions of the authors are their own and do not necessarily reflect the view or position of the Trustee Council.

\section{References}

Acevedo-Whitehouse K, Duffus LJ (2009) Effects of environmental change on wildlife health. Philosophical Transactions of the Royal Society B, 364, 3429-3438.

Altschul SF, Gish W, Miller W, Myers EW, Lipman DJ (1990) Basic local alignment search tool. Journal of Molecular Biology, 215, 403410.

Ballachey BE, Bodkin J, Howlin S, Doroff A, Rebar A (2003) Correlates to survival of juvenile sea otters in Prince William Sound, Alaska, 19921993. Canadian Journal of Zoology, 81, 1494-1510.

Bartosiewicz M, Penn S, Buckpitt A (2001) Applications of gene arrays in environmental toxicology: fingerprints of gene regulation associated with cadmium chloride, benzo(a)pyrene, and trichloroethylene. Environmental Health Perspectives, 109, 71-74.

Beineke A, Siebert U, Muller G, Baumgartner W (2007) Increased blood interleukin-10 mRNA levels in diseased free-ranging harbor porpoises (Phocoena phocoena). Veterinary Immunology and Immunopathology, 115, 100-106.

Bommer UA, Thiele BJ (2004) The translationally controlled tumour protein (TCTP). International Journal of Biochemistry and Cell Biology, 36, 379-385.

Bowen L, Aldridge B, Beckmen K et al. (2006) Differential expression of immune response genes in Steller sea lions: an indicator of ecosystem health? EcoHealth, 3, 109-113.

Bowen L, Schwartz J, Aldridge B et al. (2007) Differential gene expression induced by exposure of captive mink to fuel oil: a model for the sea otter. EcoHealth, 4, 298-309.

Burchiel SW, Luster MI (2001) Signaling by environmental polycyclic aromatic hydrocarbons in human lymphocytes. Clinical Immunology, 98, 210.

Burczynski ME, McMillian M, Ciervo J et al. (2000) Toxicogenomics-based discrimination of toxic mechanism in HepG2 human hepatoma cells. Toxicological Science, 58, 399-415.

De Maio A (1999) Heat shock proteins: facts, thoughts, and dreams. Shock, 11, 1-12.

Dong L, Ma Q, Whitlock JP Jr (1997) Down-regulation of major histocompatibility complex Q1b gene expression by 2,3,7,8-tetrachlorodibenzo-p-dioxin. The Journal of Biological Chemistry, 272, 29614-29619.

Estes JA (2009) Ecological effects of marine mammals. In: Encyclogpedia of Marine Mammals (eds Perrin WF, Wursig B \& Thewissen JGM), pp. 357-361. Elsevier, Amsterdam.

Estes JA, Duggins DO (1995) Sea otters and kelp forests in Alaska: generality and variation in a community ecology paradigm. Ecological Monographs, 65, 75-100.
Estes JA, Bacon CE, Jarman WM, Norstrom RJ, Anthony RG, Miles AK (1997) Organochlorines in sea otters and bald eagles from the Aleutian archipelago. Marine Pollution Bulletin, 34, 486-490.

Estes JA, Terborgh J, Brashares JS et al. (2011) Trophic downgrading of planet earth. Science, 333, 301-306.

Ghanem MM, Batelli LA, Mercer RR et al. (2006) Apoptosis and Bax expression are increased by coal dust in the polycyclic aromatic hydrocarbon-exposed lung. Environmental Health Perspectives, 114, 1367-1373.

Goldsby RA, Kindt TJ, Osborne BA, Kuby J (2003) Immunology, 5th edn. WH Freeman and Company, New York.

Harris SG, Padilla J, Koumas L, Ray D, Phipps RP (2002) Prostaglandins as modulators of immunity. Trends in Immunology, 23, 144-150.

Harvell CD, Kim K, Burkholder JM et al. (1999) Emerging marine diseases-climate links and anthropogenic factors. Science, 285, 1505-1510.

Iwama GK, Mathilakath MV, Forsyth RB, Ackerman PA (1999) Heat shock proteins and physiological stress in fish. American Zoologist, 39, 901-909.

Jenne DE, Tschopp J (1989) Molecular structure and functional characterization of a human complement cytolysis inhibitor found in blood and seminal plasma: identity to sulfated glycoprotein 2, a constituent of rat testis fluid. Proceedings of the National Academy of Sciences of the United States of America, 86, 7123-7127.

Johnson CK, Tinker MT, Estes JA et al. (2009) Prey choice and habitat use drive sea otter pathogen exposure in a resource-limited coastal system. Proceedings of the National Academy of Sciences of the United States of America, 106, 2242-2247.

Kibenge MJT, Munir K, Kibenge FSB (2005) Constitutive expression of Atlantic salmon Mx1 protein in CHSE-214 cells confers resistance to Infectious Salmon Anaemia virus. Virology Journal, 2, 75.

Krumm B, Mengb X, Lia Y, Xiangb Y, Denga J (2008) Structural basis for antagonism of human interleukin 18 by poxvirus interleukin 18-binding protein. Proceedings of the National Academy of Sciences of the United States of America, 105, 20711-20715.

Ma Q, Geng Y, Xu W et al. (2009) The Role of translationally controlled tumor protein in tumor growth and metastasis of colon adenocarcinoma cells. Journal of Proteome Research, 9, 40-49.

Mancia A, Warr GW, Chapman RW (2008) A transcriptomic analysis of the stress induced by capture-release health assessment studies in wild dolphins (Tursiops truncatus). Molecular Ecology, 17, 2581-2589.

McLoughlin K, Turteltaub K, Bankaitis-Davis D et al. (2006) Limited dynamic range of immune response gene expression observed in healthy blood donors using RT-PCR. Molecular Medicine, 12, 185-195.

Monson DH, McCormick C, Ballachey B (2001) Chemical anesthesia of northern sea otters (Enhydra lutris): results of past field studies. Journal of Zoo and Wildlife Medicine, 32, 181-189.

Oesch-Bartlomowicz B, Oesch F (2005) Phosphorylation of cytochromes P450: first discovery of a posttranslational modification of a drugmetabolizing enzyme. Biochemical and Biophysical Research Communications, 338, 446-449.

Quintana FJ, Basso AS, Iglesias AH et al. (2008) Control of T(reg) and $\mathrm{T}(\mathrm{H}) 17$ cell differentiation by the aryl hydrocarbon receptor. Nature, 453, 46-47.

Raisuddin S, Kwok KWH, Leung KMY, Schlenk D, Lee J (2007) The copepod Tigriopus: a promising marine model organism for ecotoxicology and environmental genomics. Aquatic Toxicology, 83, 161-173.

Ramesh A, Walker SA, Hood DB, Guillen MD, Schneider K, Weyand EH (2004) Bioavailability and risk assessment of orally ingested polycyclic aromatic hydrocarbons. International Journal of Toxicology, 23, 301-333.

Rigopoulou EI, Abbott WG, Haigh P, Naoumov NV (2005) Blocking of interleukin-10 receptor-a novel approach to stimulate T-helper cell type 1 responses to hepatitis C virus. Clinical Immunology, 117, 57-64.

Robinson J, Waller M, Parham P, Bodmer JG, Marsh SGE (2001) IMGT/HLA database-a sequence database for the human major histocompatibility complex. Nucleic Acids Research, 29, 210-213.

Schwartz JA, Aldridge BM, Lasley BL, Snyder PW, Stott JL, Mohr FC (2004a) Chronic fuel oil toxicity in American mink (Mustela vison): 
systemic and hematological effects of ingestion of a low-concentration of bunker C fuel oil. Toxicology and Applied Pharmacology, 200, 146-158.

Schwartz JA, Aldridge BM, Stott JL, Mohr FC (2004b) Immunophenotypic and functional effects of bunker $\mathrm{C}$ fuel oil on the immune system of American mink (Mustela vison). Veterinary Immunology and Immunopathology, 101, 179-190.

Sitt T, Bowen L, Blanchard MT et al. (2008) Quantitation of leukocyte gene expression in cetaceans. Developmental and Comparative Immunology, 32, 1253-1259.

Tabuchi M, Veldhoen N, Dangerfield N, Jeffries S, Helbing CC, Ros PS (2006) PCB-related alteration of thyroid hormones and thyroid hormone receptor gene expression in free-ranging harbor seals (Phoca vitulina). Environmental Health Perspectives, 114, 1024-1031.

Tanabe S, Iwat H, Tatsukawa R (1994) Global contamination by persistent organochlorines and their ecotoxicological impact on marine mammals. Science of the Total Environment, 154, 163-177.

Terborgh J, Estes J (eds) (2010) Trophic Saxcades: Predators, Prey, and the Changing Dynamics of Nature. Island Press, Washington D.C., 464 pp.

Tsai MJ, O'Malley BW (1994) Molecular mechanisms of action of steroid/thyroid receptor superfamily members. Annual Review of Biochemistry, 63, 451-486.

Tsan M, Gao B (2004) Cytokine function of heat shock proteins. American Journal of Physiology_Cell Physiology, 286, C739-C744.

Tumpey TM, Szretter KJ, Van Hoeven N, Katz JM et al. (2007) The Mx1 gene protects mice against the pandemic 1918 and highly lethal human H5N1 influenza viruses. Journal of Virology, 81, 10818-10821.

Tuynder M, Fiucci G, Prieur S et al. (2004) Translationally controlled tumor protein is a target of tumor reversion. Proceedings of the National Academy of Sciences of the United States of America, 101, 15364-15369.

Veldhoen M, Hirota K, Westendorf AM et al. (2008) The aryl hydrocarbon receptor links TH17-cell-mediated autoimmunity to environmental toxins. Nature, 453, 106-109.

Walton RM (2001) Establishing reference intervals: health as a relative concept. Seminars in Avian and Exotic Pet Medicine, 10, 66-71.

Wegner KM, Kalbe M, Rauch G, Kurtz J, Schaschl H, Reusch TBH (2006) Genetic variation in MHC class II expression and interactions with MHC sequence polymorphism in three-spined sticklebacks. Molecular Ecology, 15, 1153-1164.
Wendell F, Pattison C, Harris M (1996) Sea Otter, Enhydra lutris, containment management: field studies and feasibility assessment. Calif Fish Game, Administrative Report 96-5, 10 pp.

Williams TD (1983) Hematology and blood chemistry in the sea otter (Enhydra lutris). Journal of Wildlife Diseases, 19, 44-47.

Williams TD (1992) Influence of age, sex, capture technique, and restraint on hematologic measurements and serum chemistries of wild California sea otters. Veterinary Clinical Pathology, 21, 106-111.

Zheng S, Song Y, Qiu X, Sun T, Ackland ML, Zhang W (2008) Annetocin and TCTP expressions in the earthworm Eisenia fetida exposed to PAHs in artificial soil. Ecotoxicology and Environmental Safety, 71, 566573.

\section{Data Accessibility}

DNA sequences: uploaded as Supporting Information.

Data underlying Fig. 1 and Table 4 have been deposited at Dryad: doi:10.5061/dryad.1nn7v.

\section{Supporting Information}

Additional supporting information may be found in the online version of this article.

Table S1 Nucleotide sequences amplified from sea otter (Enhydra lutris) cNDA by real-time PCR primer pairs.

Please note: Wiley-Blackwell are not responsible for the content or functionality of any supporting information supplied by the authors. Any queries (other than missing material) should be directed to the corresponding author for the article. 